\title{
Real Activities Manipulation (RAM) and Accrual- based Earning Management Pre and Post IFRS Adoption in Indonesia
}

\author{
Dyah Purwanti \\ Politeknik Keuangan Negara (PKN) STAN \\ dyahpurwanti@gmail.com
}

\begin{abstract}
The purpose of this study is to investigate the impact of the adoption of International Financial Reporting Standards (IFRS) on accrual-based earnings management (EM) and real activities manipulations (RAM). The research is motivated by the fact that past studies have indicated the existence of no significance levels of earning management for Indonesia in particular before IFRS. We used t-test paired sample and regression analysis, and used sample of manufacturing companies listed in the Indonesia Stock Exchange, in the timeframe 2010-2014. We find evidence statistically significant shift from accrual-based earning management to RAM after the adoption of IFRS, indicating the replacement of one form of earning management with the other. Another result of this study is the accrual-based earnings management practices statistically significant differ (downward) in the period pre and post the adoption of IFRS, while RAM practices significantly differ (upward) between period pre and post the adoption of IFRS, and except RAM measured by abnormal CFO. While the results of two other RAM was measured by abnormal production and abnormal discretionary expense differ significantly (upward) in the period after the adoption of IFRS.
\end{abstract}

Keywords- abnormal cash flows, abnormal production, abnormal discretionary expenses, accrual-based earning management, discretionary accruals, earning management, IFRS adoption, Real activities manipulation (RAM)

\section{INTRODUCTION}

Since 2012, Indonesia adopt international accounting standards known as International Financial Reporting Standards (IFRS), which IFRS is a single standard accounting reporting of high quality. IFRS has principle-based accounting framework that includes professional' assessment with strong disclosure, clear and transparent regarding the economic substance of transactions. So IFRS requires more explanation to reach certain conclusions, and more explanation to the related accounting transactions.

IFRS apply standards based on the principle, known as principle-based, that expected to improve the accounting quality. The higher accounting quality can be reflected in the increasing value relevance of accounting information, decreasing earnings management and increasing timeliness of loss recognition (1). Theoretically, convergence to IFRS is considered would reduce earnings management. Conducted asset valuation properly with the concept of fair value, is considered to reduce earnings management.

Earnings management is defined as management actions to choose accounting policies, intended to improve financial performance, and it will lead to maximize stockholders' wealth and increasing the market value of the company (2). The result of earning management and IFRS adoption research proved variously evidence. The quality of accounting can be increased if the management of opportunistic policies can be restricted, for example in earning management (1). Hutagaol (2010), Barth et al. (2008), Rahmellia (2009) shows that earnings management post the adoption of IFRS is lower compared to the previous period, and the value relevance of earnings post the adoption period is higher than in the previous period. Instead previous research showed an increase in accrual earnings management and real terms in the period following the adoption of IFRS (3).

Earnings management consists of accrual-based earnings management and real earnings management or real activities manipulation (RAM). Accrual-based earnings management was done by manipulating the accrual method that are not directly related to cash flow. Accrual is based on certain methods and estimation. Earnings management can be executed in two ways, through manipulation of accruals and real earnings management or RAM. However, most of previous earnings management research focused only on the accrual-based earning management.

Since the current earnings management research is stating to the importance of understanding how companies conduct earnings management through real earnings management in addition to accrual-based earnings management. The method used in the manipulation of real activities through over production. So, the fixed overhead production costs can be allocated to the larger number of units, and it caused the fixed costs per unit will be lower and the cost of producing goods will be smaller (4).

The issue of the adoption of IFRS could decrease earning management. YP Senjani suspect behavior change in the earnings management practices in the post implementation of IFRS, from the accrual basis to the real basis for an effective change in the standard per-2012. It may affect the behavior in 
use earning management to improve financial performance (5). If in the prior adoption of IFRS, the company has a tendency to do accrual-based earnings management but in the post adoption of IFRS companies tend to use real earnings management.

The real earnings management is measured by cost approach which refers to the measurement developed by Roychowdhury (4). The motivation of this study include inconsistencies related to the impact of IFRS on earnings management. Rudra and Bhattacharjee found implementation Indian domestic accounting standards is better, but the results indicate that the adoption of IFRS in India could increase earnings management (6). This may be due to the managers' opportunity to influence the outcome of the estimating fair value by selecting an accounting method. Callao et.al (2007) examines the comparability and relevance of financial statements post the application of IFRS in Spain. Callao et.al (2007) argues that the application of IFRS affect the value of current assets due to the use of fair value, while the fixed assets after IFRS implementation does not produce a significant difference for many companies, and still choose acquisition cost . Zang (2012) said that the accrual-based earnings management alone could not explain the overall earnings management practices.

\section{ACCRUAL-BASED EARNING MANAGEMENT AND REAL- ACTIVITIES MANIPULATIONS (RAM)}

The concept of earnings management used the agency theory approach. The agency theory focuses on two individuals, the principal and the agent which each party are trying to maximize their self-interest, rising a conflict of interest between the principal and the agent (2). A manager will choose one of the accounting methods or the specific policy that allowed in the GAAP since it could be maximizing their utility or could increase the value of the company. How the manager use systematically to affect earnings figures and deliberately by selecting accounting policies and procedures aimed at maximizing the utility of certain accounting manager and the stock price, the behavior is called earnings management (earnings management).

Earning management is an intervention on the part of to manage earnings by raising or lowering the accounting profit, by exploiting or looseness accounting methods and accounting procedures. That is accomplished because accounting standards allow the companies to choose one of the accounting method (7). The motivation to perform earnings management is usually caused by "pressure" from both inside and outside the company. The pressure from the inside of the company usually associated with financial prominent that do not reach the targets. The motivation is more taught when the financial performance associated with "reward" in the form of financial incentives, such as bonuses or to get maximum compensation (8). While the motivation from outside, usually it comes from top management who want to show their performance to the principal, which the company's financial performance has increased. Especially when companies are publicly traded companies, the top management wanted to demonstrate to shareholders that they are reliable leadership. The tendency will be stronger, when the actual data is only under a little from the desired target. Then earnings management function is to "refine" to the financial statements better.

In relation to capital markets, earnings management is also executed by the managers if there is a "gap" between the performances of the company with the expectations of the capital market analysis. Managers will aggressively make financial statements in line with a "forecast" of the capital market analysts. Another motivation is making financial statements more attractive and appealing in an effort to apply for a loan (loan application) or to carry out an IPO (Initial Public Offering).

The earnings management occurs when managers use policies in financial reporting and structuring transactions to alter financial statements that mislead the stakeholders about the company's performance or to affect the contract based on the numbers in the financial statements (9). And earnings management is generally divided into two categories: earnings management through accounting policies (accrual) and earnings management through real activities. The accrual transactions can be tangible as : (1) the transaction is nondiscretionary accruals (NDA), when the transaction has been accounted for using a particular method, the management expected to be consistent with that method and, (2) the transaction discretionary accruals (DA), a method that gives freedom to the management flexibility to determine the amount of the accrual transactions (10). The accrual account is often used by management to manage earnings (11).

The companies do the real earnings management trying to avoid losses by offering "deep" discounted prices for a while in order to increase sales, perform excessive production to lower cost of goods sold (COGS), and reducing discretionary spending or expenses to increase margins (4). The effect of applying IFRS in Spain especially for comparability and relevance of financial statements proved empirically by Callao, et al. (2007) (4). The companies listed on the Spanish Stock Exchange have been required to apply IFRS since January 2005. The results showed that with the local rules of the comparability of financial statements have lower, and implementation of IFRS has widened the difference between the book value and fair value.

Higher quality accounting by IFRS than local standards and the the companies still choose to use local standards is a mistake. In some cases IFRS predicted able to control earnings management, but the evidence is showed that the application of IFRS in India did not lower earnings management (6).

Discretionary accruals is obtained by subtracting the nondiscretionary accruals of total accruals. Non-discretionary accruals are estimated using a regression model that regression total accruals on several explanatory variables. However, the weakness of the total accrual approach is that we cannot distinguish the discretionary component of the nondiscretionary component. Therefore, it needs to be developed to separate discretionary accruals of total accruals and it was proven effective (12).

Based on the evidence of previously research and the analysis on earning management concept, we developed two hypotheses as follows: 
Hypothesis 1: there are differences in accrual-based earnings management practices pre and post the adoption of IFRS

Hypothesis 2: there are differences in RAM practices pre and post the adoption of IFRS.

\section{RESEARCH METHOD}

The samples are manufacturing companies, were selected based on certain criteria (purposive sampling). The criteria depend on the availability of components in the information published in annual financial statements. The consideration of the cut-off time of implementation is mandatory IFRS implementation, 2012 be used as the basis for determining the period pre and post the implementation of IFRS. And IFRS specified period pre implementation is 2010 to 2012 . The post implementation period is 2013 to 2014.

The dependent variable in this study is the management of accrual-based earnings management by 2 approach measurement, the Modified Jones by Dechow and the Modified Jones by Kothari, and real activities manipulation measured by 3 cost approach, abnormal CFO, abnormal production cost and abnormal discretionary expenses. The independent variable is the period of the implementation of IFRS. This research was taking the data prior to implementation was the year of pre and the year of post IFRS implementation.

The criteria for the completed sample is presented below.

- The manufacturing companies data that completely for the period 2010-2014 for the calculation of earnings management component uses real production cost approach requires $\mathrm{t}-1$, one year prior to the year $\mathrm{t}$,

- Companies that publishes an annual report which ended on December 31 during the observation period.

- The financial statements using the currency in Rupiah.

- The companies do not across the industrial sector.

The secondary data is used in this research taken from the Indonesia Stock Exchange on information publicly listed firms. Such data includes accrual-based earning management components and real earning management components using an approach that is the cost of production to its components explanatory power sales (sales), changes in sales (DSales), changes in sales in the previous year (DSalest-1) against BPROD. The data was obtained through a site owned by the Indonesian Stock Exchange (BEI), among which www.idx.co.id and from Indonesian Capital Market Directory (ICMD) (see Table 1 appendix).

The earnings management was measured by discretionary accruals and abnormal CFO, abnormal production, abnormal discretionary expense, counted with many approach as follows:

- $\mathrm{EM}_{1}=$ accrual-based earning management, measured by discretionary accrual - Modified Jones by Dechow.

- $\mathrm{EM}_{2}=$ accrual-based earning management, measured by discretionary accrual - Modified Jones by Kothari

- $\mathrm{EM}_{3}=\mathrm{RAM}_{1}=$ real activities manipulations, measured by Abnormal Cash Flows from Operating Activities (CFO)
- $\mathrm{EM}_{4}=\mathrm{RAM}_{2}=$ real activities manipulations, measured by Abnormal Production

- $\mathrm{EM}_{5}=\mathrm{RAM}_{3}=$ real activities manipulations, measured by Abnormal Discretionary Expenses.

Data analysis technique used t-test (paired sample t-test) to compare the average of the two paired samples is to see whether the same or different at the significance (0.05) level. We also used ANOVA Test for processing data in order proving the hypothesis and the regression analysis by SPSS 23 .

\section{FINDINGS AND DISCUSSIONS}

The results of descriptive statistical analysis was presented in Table 2, 3 and 4 Appendix. Table 2 reports the descriptive statistics (means and standard deviations and numbers of observations) for a range of variables for all of our sample firm-year observations using data from Indonesia Stock Exchange for the period immediately preceding (2011-2012) and following (2013-2014) the introduction of IFRS in Indonesia.

Next, we analyzed by the paired-sample t-test on earnings management, either accrual earnings management or manipulation of real activity (RAM) pre and post IFRS implementation. Table 3 Appendix, reports the paired t-test with one sample and the paired t-test with two sample. The criteria of result test were the comparison of t-test and t-table, if t-test > t-table, then $\mathrm{H}_{0}$ is rejected, it means there are significant differences. If t-test $<\mathrm{t}$-table, then $\mathrm{H}_{0}$ is accepted, and it's meaning no significant difference.

The results reported in Table 3 Appendix showed the existence of significance (at 5 percent significance level) both of accrual-based earning management (Model 1 and Model 2) and real activities manipulations (RAM). The comparison earning management practices before and after IFRS adoption is significantly differ. Interestingly, in the case Indonesian firms, the absolute mean value of accrual-based EM is lower after IFRS adoption period. More importantly, we provide evidence of statistically significant decrease in accrual-based EM for the period after, in comparison to that prior period. Hypothesis 1 is accepted.

On the other hand, there is increasing RAM practices after IFRS adoption, except RAM presented by abnormal CFO. Most importantly, in the period following adoption of IFRS, we provide evidence on statistically significant (upward) RAM using RAM proxy by abnormal production and RAM proxy by abnormal discretionary expenses. The hypothesis 2 is accepted.

The findings from Table 3 as a whole indicate a significance decrease in accrual-based EM and a significant increase in RAM for the period immediately after, compared to before, IFRS adoption for Indonesian listed companies.

Furthermore, the result in Table 3 also indicate a shift from accrual-based EM to RAM after the introduction of IFRS in 2012, when comparing accrual-based EM and RAM measures from the pre- and post-adoption period.

In additional test, we perform different tests on two groups of earnings management proxy at the top, accrual earnings management and RAM, pre and post the adoption of 
IFRS. Using ANOVA test, and the results are presented in Table 4 in the Appendix. T-test 1,651 (one-tail) and 1.970 (two-tail) is smaller than the t-table for 3.892, and also the probability value ( $\mathrm{p}$-value) is $0.000<0.05$, then $\mathrm{H}_{0}$ is rejected, and it means there is a significant difference accrual earnings management and RAM in the pre and post the adoption of IFRS.

The overall result also indicate a shift from accrual-based EM to RAM after the adoption of IFRS in 2012, when comparing mean of the accrual-based EM and the RAM measures from the pre- and post- implementation period.

Changes in the behavior of the use of earnings management can be caused by factors outside of the accounting standards. Declining economic conditions and also some new tax policies of the company, making the company managers trying to manage its earnings figures (13).

The results of this study are not aligned with the previous research by Senjani (2012), Jeanjean \& Stolowy (2008), Callao et al. (2010), Rudra and Bhattacharjee (2012) which states that the adoption of IFRS did not decrease or increase the accrual earnings management practices. Further, Jeanjean and Stolowy (2008) states that in countries that do not have adequate protection against the investor, the adoption of IFRS has not been proven to improve the quality of accounting information.

Otherwise, the results of this study support the previous research by Roychowdhury (4), Ferentinou et al (2014), Leuz et al (2003), Nurmala Ahmar, concluded the post adoption of IFRS managers tend to move in a pattern of conduct earnings management (14). It is expected that IFRS requires more disclosure makes managers assign to the real activity in managing its earnings figures.

Thus, firms may have been left with a decreased motivation for downward accrual-based EM after IFRS adoption, but at the same time, they have also possibly been left with fewer tools in place by which to affect reported income through choices in accounting policies, i.e. by engaging in accrualbased EM. However, the observed shift from one form of EM to another possibly reveals an unintended consequences of IFRS implementation, in the sense that RAM indeed represents a form of EM, with corresponding consequences for the quality and relevance of accounting information resulting from this form of EM.

\section{CONCLUSION AND SUGgestions}

This study aims to provide empirical evidence of differences in practice of real earnings management (RAM) and accrual-based earning management pre and post implementation of IFRS in Indonesia. Samples were manufacturing companies are selected based on criteria. A total of 86 samples were tested with 5 used measurement model of earnings management. The fifth models consist of three model of real earnings management (RAM), approach to production expenses, operating cash flow and discretionary expenses and the 2 (two) models of the accrual-based discretionary. The two models discretionary accrual approach is the Modified model by Jones and the modified model by Kothari.

As of the results, we can conclude that accrual-based earnings management practices statistically significant differ in the period pre and post the adoption of IFRS, both of accrualbased EM and RAM practices. Accrual-based earnings management is measured by the Modified Jones Approach and the Modified Kothari approach, was different at the time before and after the adoption of IFRS. It supports several previous research studies both in Indonesia and abroad. Mandatory application of IFRS was able to change the accrual earnings management practices and indicated shifting form EM, so this led to the idea for further research to investigate the motivation of shifting form EM.

One limitation of this study is a coverage period. This research was conducted in 2016 with the publication of the latest data in 2014. Implementation of IFRS applicable mandatory in 2012, as a result comparisons can only be made for two year pre and two year post. Another limitation of this study is not to use measurements other than the Modified Jones and Kothari, resulting in advanced research are expected to use more accrual earnings management proxy, and can produce accurate measure to detect discretionary accrual.

\section{REFERENCES}

[1] Barth ME. International Accounting Standards and Accounting Quality. Journal of Accounting Research. 2008; 46 No 3.

[2] Scott WR. Financial Accounting Theory New Jersey: Prentice Hall; 2009.

[3] Callao S\&JIJ. Have IFRS Affected Earnings Management in the European Union? Accounting in Europe. 2010; 7 No 2: p. 159-189.

[4] Roychowdhury S. Earnings Management Through Real Activities Manipulation. Journal of Accounting and Economics. 2006;: p. 335-370.

[5] Senjani YP. Manajemen Laba Berbasis Akrual dan Riil Sebelum dan Sesudah Adopsi IFRS. Tesis Sarjana Universitas Gajah Mada. 2012.

[6] Rudra T,BCAD. Does IFRS Influence Earnings Management? Evidence from India. Journal Management Research. 2012; 4.

[7] Cahyati. Implikasi Tindakan Perataan Laba terhadap Pengambilan Keputusan oleh Investor. Jurnal Riset Akuntansi dan Komputerisasi. 2011; 2 No 1 .

[8] Lestari YO. Konvergensi International Financial Reporting Standards (IFRS) dan Manajemen Laba di Indonesia. Jurnal Akuntansi Fakultas Ekonomi. 2012.

[9] Healy PM,WJ. A Review of The Earnings Management Literature and Its Implications for Standard Setting. Accounting Horizon. 1999; 13 (4): p. 365-383.

[10] Gumanti TA. Earnings Management : Suatu Telaah Pustaka. Jurnal Akuntansi dan Keuangan. 2004; 2 (2): p. 104-115.

[11] Ball R,SL. The Role of Accruals in Asymmetrically Timely Gain and Loss Recognition. Journal of Accounting Research. 2006; 44 (1-2): p. 207-242.

[12] Dechow PM,SRG,aSAP. Detecting Earning Management. The Accounting Review. 1995; 70 (21): p. 193-225.

[13] Wagenhofer, A \& R. Ewert. Economics Effect of tightening accounting standards to restrict earning management. The Accounting Review. 2005; 8 No. 4.

[14] Ahmar N. Model Manajemen Laba Akrual dan Riil Berbasis Implementasi IFRS. Jurnal Akuntansi dan Keuangan. 2016. 